\title{
The Visionary Companies, an Excellent Case of the Informal Systems Thinking ${ }^{1}$
}

\author{
Matjaz Mulej, Zdenka Zenko, and Vojko Potocan \\ University of Maribor, Faculty of Economics and Business, \\ Maribor, Slovenia
}

mutej@uni-mb.si zotenka.zenko@uni-mb.si voiko.potocan@uni-mb.si

\section{Abstract}

Systems theory has become a worldview aimed at holism, and a methodology supportive of holism. But it has also become a sophisticated mathematical and philosophical approach, which limits it to rather few intellectuals and systems theorists. This is not enough for humankind to do well. An insight into the most successful companies, called the visionary companies in the analysis briefed here, let us see that an informal, implicit, indirect, systems thinking might be as important as the systems theory (which still remains important as its aide). The point is double, at least: (1) systems thinking practices holistic thinking that implicitly attains the requisite holism on a high level, (2) systems theory is not a theory aimed at itself, but at supporting the holistic rather than one-sided thinking, by building bridges between mutually different specialists. Informal, implicit systems thinking can do equally much good as the one backed by systems theory.

Keywords: Bertalanffy, business success, holism, informal systems thinking, systems theory, unsystemic thinking, visionary companies, worldview.

\section{The Selected Problem and Viewpoint of Dealing With it}

Companies working in the arena of hardware and software supporting communication tend to call their area informatics. There are many more who call themselves the same way with an equally full right, such as librarians, business evidence / intelligence people, journalists etc. In »informing sciences « they are all granted their right to coexist. Thus, this is not the problem to worry about much. We find more important another issue: the field of communication and information technology is growing very rapidly, facing a growingly fierce competition, too. Who will survive, seems to depend a lot on their creativity and its transformation in invention ${ }^{2}$, potential innovation ${ }^{3}$ and innovation ${ }^{4}$. In terms of this fact it is worthwhile to take a look at the experience of the companies, which are called the visionary companies 5 . They proved to be very creative and extremely successful in a quite long run, and one should learn from them. In order to be so they also use a lot of systemic, i.e. holistic thinking ${ }^{6}$, without using the formal language of the (general) systems theory. Let us first examine what we mean by this, and then brief the experience of the socalled visionary companies.

\section{V. Bertalanffy's "General Systems Theory” as a Worldview Close to the Most Modern Business}

Material published as part of these proceedings, either on-line or in print, is copyrighted by Informing Science. Permission to make digital or paper copy of part or all of these works for personal or classroom use is granted without fee provided that the copies are not made or distributed for profit or commercial advantage AND that copies 1) bear this notice in full and 2) give the full citation on the first page. It is permissible to abstract these works so long as credit is given. To copy in all other cases or to republish or to post on a server or to redistribute to lists requires specific permission from the publisher at Pubtisthel@intormingscience.org
Since his first famous research, as a biologist and mathematical biologist, from 1928 on, Ludwig von Bertalanffy (LvB) has gradually become the founding father of the General Systems Theory (GST). This notion is now called a theory, which might recall us of time-free findings. In the case of LvB, 
as quoted by Elohim (Elohim, 1999; Elohim, 2000) after Davidson (1983) and other references and sources, GST is not called a theory rightly. What LvB required, was GST to become a teaching (»Lehre «) with the role of a new worldview, which would ask all of us:

- to feel and act as a citizen of the entire world, not single nations only;

- to consider the entire biosphere as one system / whole;

- to see the planet Earth as one organisation, which means a whole with attributes emerging from interdependencies, sometimes mutually reinforcing, sometimes mutually opposing, between its parts on the basis of their interactions.

This LvB's notion, actually, means a warning: limitations of our thinking and resulting acting cause too many oversights for the biosphere, including the humankind of today, to have a good chance to survive rather than to disappear, sooner or later. Obviously, LvB's worldview has not received sufficient humankind's attention and consideration, over the five decades since he established (with a few other broadminded scientists) the GST.

Why? Bertalanffy (rightly, from his viewpoint) required what we might call a total-system approach. To most humans, this is more than they find requisite (i.e. both necessary, sufficient and possible ${ }^{7}$ ) in their own work and life framework. The idea of the GST as a very broad worldview has, gradually, come to be a good formal methodology, which transfers some important insights from one specialised discipline to another and lets them benefit from transfers rather than from interdisciplinary cooperation (see: EMCSR etc., incl. EMCSR, 2002). A lot of benefit results, but the concept remains far away from LvB: Systems thinking as the practice of holistic thinking comes to be partially holistic. ${ }^{8}$

Systems theory, as its theoretical reflection and background, comes to be supportive of such partial holisms, as GST, in practice. 9

Reductionism, which has been a very useful scientific approach for several centuries, but keeps being so only partially, comes to be fortified rather than partly replaced and partly complemented with a more holistic, interdisciplinary and trans-disciplinary approach. ${ }^{10}$

The traditional human selfishness is not holistic and is allowed to remain one-sided. But, humans need to include more interdependence into criteria of a good work and life, in order to be able to survive (Mulej, Kajzer, Potocan, Knez-Riedl 2000). ${ }^{11}$

As a result of such practical shortcomings of GST as a - basically - nice and insightful theory, beside / on the basis of GST, other methodologies of holism surfaced inside and outside the systems movement (Jackson 1991), such as the chaos and complexity theories, (our own) Dialectical Systems Theory, etc. (Mulej et al. 2000, and earlier, since 1974). The role of GST was reduced to one of many systems theories.

Let us take a look at the usual business style from this viewpoint! Its consequences are, e.g. profits and at the same time ruining the rain-forest around the Amazonas river on an area as big as Slovenia and a half yearly, disappearance of the Aral Sea lake in Russian Asia, etc. United Nations, in their 1992 conference on sustainable development in Rio de Janeiro, and the later-on following conferences, have actually (tacitly) required the ideas by LvB to be revived and practiced - in both politics and business. As we see from reports from those conferences, important words tend to be said and written, but influential biased-interest lobbies tend to neglect them, around the world. The current globalisation may be seen as a new danger for mankind to work along the lines of sustainable development, trying to create more profit of the biggest companies and economies rather than to produce their and general interest in holistic thinking and acting in the daily local life ${ }^{12},{ }^{13}$. (Brudenius et al. 1999; Forrester 1996; Vezjak, Stuhler, Mulej 1997; Jenner; 
1998; Kirn, ed. 1991; Martin, Schurmann 1996; Hersh 1995; etc.). - Profits are attained and lost by the same actions. A new style of thinking is badly needed. ${ }^{14}$

The need is stated. But, if we humans are stating a need, this means that practice, sometimes also theory / science, is lacking responses to this need, and our humankind's capability demonstrates holes rather than wholes.

Systems theory has developed as a methodology, too, not only as a worldview. Experience says, that the extremely broad thinking, which is required from us by LvB, reaches beyond limits of capabilities, values, ethics and interest of nearly all men and women on the planet Earth. Humans need a simpler and still realistic, less general (and hence less oversimplifying) approach. This fact might be a reason that the GST is not much supported any more, in practice. New theories of a very similar orientation, which tends toward holism, general isomorphysms and common policies / rules have shown up over the last decades.

But we will not deal with theory here. We will rather demonstrate that systems thinking can be very informal and successful with no word of theory. This is demonstrated e.g. by the so-called visionary companies, among them some are also from the area of communication and information technology (See: Collins, Porras 1997).

Why would this matter to you? Well, as an influential person / organization you, quite probably, are trying to make a difference, to be a change agent. (Rogers 1995) You tend to be a manager in the broadest sense of this word, which is: you try to succeed using available resources (Belak 2000). You find the situation in your market both complex and complicated (Potocan 2001, Schiemenz in Mulej et al. 2000, etc.) and you understand that you have better chances to succeed if you think different (Milosevic 2000) and behave in your own way, trying to find unusual ways in usual situations (Pecjak 2001). You try even to do what other find impossible.

If you can say »Yes, actually, kind of « to the briefed statements about your conditions of working and living, then you may be used to the need for some informal systems thinking. And you have been using it whenever successful, tacitly. (See Table. 1)

\begin{tabular}{|l|l|}
\hline Systems / Systemic / Holistic Thinking & Unsystemic, Traditional Thinking \\
\hline Interdependence/s, Relation/s, Openness & Independence, Dependence, Closeness \\
\hline Complexity (and Complicatedness) & Simplicity, or Complicatedness only \\
\hline Attractor/s & No influential force/s, but isolation \\
\hline Emergence & No process of making new attributes \\
\hline Synergy, System & No new attributes resulting from relations \\
\hline Whole and holism & Parts and partial attributes only \\
\hline Networking, Interaction, Interplay & No mutual influences \\
\hline
\end{tabular}

Table. 1: The Basic Seven Terms of Systems / Systemic / Holistic versus Unsystemic Thinking The visionary companies provide for a very impressive proof of this conclusion.

\section{The 12 Shattered Myths of the Unsystemic / Traditional Concept of Management}

Science of management is not very old, especially not in Europe. This might be the reason that some conclusions about management have come to be considered realistic, over the years or decades. In meantime, life has been changing. The traditional perceptions about the basis of success present no longer a valid 
The Visionary Companies

image of reality (according to Collins/Porras 1997). They summarised the differences as follows in Table. 2:

Rethink yourself and your own practice in the terms of the Table. 2! Which column is closer to you? Is the Reality-column, in your opinion, more holistic, closer to a (informal!) systems thinking in Table. 1? If you take all twelve statements (in the Reality-column) as a dialectical system, i.e. an mental entity made of all requisite aspects and their (synergetic) relations, you will see that they are complementary a lot and remind you of everything essential for a business to be a good business in the modern conditions. In other words, here you have a very successful case of application of systems thinking with no visible (!) word of systems theory!

\begin{tabular}{|c|c|c|}
\hline No & Myth & Reality \\
\hline 1 & $\begin{array}{l}\text { It takes a great idea to start a great } \\
\text { company. }\end{array}$ & $\begin{array}{l}\text { Sometimes only. It rather takes persistence } \\
\text { of the tortoise to win a long race after a } \\
\text { slow start. }\end{array}$ \\
\hline 2 & $\begin{array}{l}\text { Visionary companies require great } \\
\text { and charismatic visionary leaders. }\end{array}$ & $\begin{array}{l}\text { Not at all. Concentration on architecting an } \\
\text { enduring institution. Clock-builders rather } \\
\text { than time tellers. }\end{array}$ \\
\hline 3 & $\begin{array}{l}\text { The most successful companies exist } \\
\text { first and foremost to maximise profits. }\end{array}$ & $\begin{array}{l}\text { A cluster of objectives, including profits, } \\
\text { but core ideology (core values and purpose) } \\
\text { matters more (and makes more money). }\end{array}$ \\
\hline 4 & $\begin{array}{l}\text { Visionary companies share a common } \\
\text { subset of »correct « core values. }\end{array}$ & $\begin{array}{l}\text { There isn't any. Deep belief in one's own } \\
\text { ideology and consistent living, breathing } \\
\text { and expressing it in all one does. }\end{array}$ \\
\hline 5 & The only constant is change. & $\begin{array}{l}\text { Except core ideology as one's reason for } \\
\text { being, along with one's powerful drive for } \\
\text { progress. }\end{array}$ \\
\hline 6 & Visionary companies play it safe. & $\begin{array}{l}\text { They combine both planned evolution, and } \\
\text { adventurous excitement challenging their } \\
\text { people and creating immense forward mo- } \\
\text { mentum, to stimulate progress. }\end{array}$ \\
\hline 7 & $\begin{array}{l}\text { Visionary companies are great places } \\
\text { to work. }\end{array}$ & $\begin{array}{l}\text { Only for those who »fit« extremely well } \\
\text { with their core ideology and demanding } \\
\text { standards, no middle ground. }\end{array}$ \\
\hline 8 & $\begin{array}{l}\text { Highly successful companies make } \\
\text { their best moves by brilliant and com- } \\
\text { plex strategic planning. }\end{array}$ & $\begin{array}{l}\text { More so by experimentation, trial and error, } \\
\text { opportunism, and - quite literary - accident. } \\
\text { More selection as found by Darwin in (self- } \\
\text { organizing) nature than as described in text- } \\
\text { books on corporate strategic planning. }\end{array}$ \\
\hline 9 & $\begin{array}{l}\text { Companies should hire outside CEOs } \\
\text { to stimulate fundamental change. }\end{array}$ & $\begin{array}{l}\text { Rarely so. Home-grown management pre- } \\
\text { vails by a factor of } 6: 1 \text {. }\end{array}$ \\
\hline 10 & $\begin{array}{l}\text { The most successful companies focus } \\
\text { primarily on beating their competi- } \\
\text { tors. }\end{array}$ & $\begin{array}{l}\text { They focus on beating themselves, they } \\
\text { never feel »we've done good enough «, but } \\
\text { ask »How can we improve ourselves do to } \\
\text { better tomorrow than we did today? }\end{array}$ \\
\hline
\end{tabular}




\begin{tabular}{|l|l|l|}
\hline 11 & $\begin{array}{l}\text { You can't have your cake and eat it } \\
\text { too. }\end{array}$ & $\begin{array}{l}\text { No tyranny of the OR, but genius of the } \\
\text { AND, rejecting to make the choice between } \\
\text { stability or progress etc. }\end{array}$ \\
\hline 12 & $\begin{array}{l}\text { Companies become visionary primar- } \\
\text { ily through »vision statements }\end{array}$ & $\begin{array}{l}\text { This is only a helpful step among thousands } \\
\text { of steps in a never-ending process of ex- } \\
\text { pressing their fundamental characteristics. }\end{array}$ \\
\hline
\end{tabular}

Table. 2: Twelve shattered myths about bases of good management

\section{Difference Between Visionary and Other Companies in Economic Terms: Holism Pays}

The so-called visionary companies, in sports terms, are gold medallists of the world market. Collins and Porras (1997) compared them with the comparison companies (silver medallists) and others. Financial results, as a consequence of their visionary (and holistic) behaviour are quite hard to believe, but real (Collins, Porras 1997, pp. 5 and 6). The gold medallists are about six times better in terms of profit than the silver medallists, and even much more (15 times!) ahead of the general market. They let us see that it pays to manage along the guidelines, which we are briefing in Tables. 1 and 2. It pays a high profit to say we are not here for profit only, and to support all the 12 statements in the Reality-column in Table. 2.

What may you conclude for yourself from these findings?

\section{Guidelines for CEOs, Managers (of all levels), and Entrepreneurs}

Collins and Porras (1997) suggest you to think of your own core ideology. What is this?

Core ideology $=$ core values + purpose

Core values $=$ The organization's essential and enduring tenets - a small set of general guiding principles; not to be confused with specific cultural or operational practices; not to be compromised for financial gains or short-term expediency.

Purpose $=$ The organization's fundamental reasons for existence beyond just making money - a perpetual guiding star on the horizon; not to be confused with specific goals or business strategies.

Both are not necessarily different from other companies, but necessarily authentic. ${ }^{15}$

In a visionary company, the core values need no rational or external justification. Nor do they sway with the trends and fads of the day. Nor even do they shift in response to changing market conditions.

When properly conceived, purpose is broad, fundamental, and enduring; a good purpose should serve to guide and inspire the organization for years, perhaps a century and more. It is never achieved or complete, it is like chasing the horizon.

A visionary company can, and usually, does, evolve into exciting new business areas yet remain guided by its core purpose.

What is what we are reporting about: words or deeds? Both. Why?

First: social psychology research strongly indicates that when people publicly espouse a particular point of view, they become much more likely to behave consistently with that point of view even if they did not previously hold that point of view.

Second: - and more important - the visionary companies do not merely declare an ideology; they also take steps to make the ideology pervasive throughout the organization and transcend any individual leader. They: 
More thoroughly indoctrinate employees into a core ideology than the comparison companies, creating cultures so strong that they are almost cult-like around the ideology.

More carefully nurture and select senior management based on fit with a core ideology than the comparison companies.

Attain more consistent alignment with a core ideology - in such aspects as goals, strategy, tactics, and organization design - than the comparison companies.

Does having and realizing a core ideology mean that visionary companies are / have been always perfect? No. But always - in general - visionary companies have placed a great emphasis on having a core ideology and have put much effort into preserving the core ideology as a vital shaping force. And - again the key point - they have done so more than the comparison companies in Collins and Porras study (1997).

Hence: articulate your own core ideology, if you do not have one yet! Examples are attached in Enclosure. Means to attain results from them are up to you, hints can be found in the quoted book by J. C. Collins and J. I. Porras (1997). It may make your thinking, decision-making, and action more holistic (in terms of Table. 1)

\section{A Brief Guide for Starting Your Formulation of Your Core Ideology}

Again, we are using quotes and findings from Collins and Porras's (1997).

What are visionary companies like? They are solid, paying attention to the fundamentals, shunning the limelight (= avoiding the theatre stage), creating jobs, generating wealth, and making a contribution to society. They are no »Icarus companies«, i.e. no high profile firms on the way up or on the way down.

What should you pay attention to? The critical question, like in a good research (which they actually are discussing, and you are supposed to do in order to produce your core ideology), is not: »What is common across a group of companies (e.g. our competitors, added by us)?«, but rather: »What is essentially different about these companies (e.g. better and worse among our competitors; our added comment)? What distinguishes one set of companies from another? « If you follow the conclusion by Collins and Porras about visionary and other companies, you may find: »The key difference is one of orientation: in visionary companies the key people had a stronger organizational orientation, they wanted to make their organizations strong independently of themselves, great and lasting organizations. « Another critical question in this respect: »Yes, you can learn most of what is required to build a visionary company, you need not be a very special natural talent.«

What do you need to be like? It is rare and difficult, but: »The test of a first-rate intelligence is the ability to hold two opposed ideas in the mind at the same time, and still retain the ability to function. ${ }^{16}$

What is the criterion for a right ideology? There is no single right ideology ${ }^{17}$. What matters is its $a u$ tencity as is the extent to which a company attains consistent alignment with its ideology, more than its contents. It is good if it gives guidance and inspiration to people inside company. Take care of the following statement, too: Do not confuse core ideology with culture, strategy, tactics, operation, policies, and other non-core practices, which are also important and must change over time.

\section{A guide for diagnosing your own organization:}

Has it made a shift in perspective from time telling (= passive follower) to clock building (= trend setter, role model)?

Does it reject the »tyranny of the $\mathrm{OR} \ll$ and embrace the »Genius of the AND«?

Does it have a drive for progress - an almost primal urge for change and forward movement in all that is not part of the core ideology? 
Does it preserve the core and stimulate progress through tangible practices, such as Big Hairy Audacious Goals (= very risky objectives), home-grown management, attitude »good enough never is «, »try a lot of stuff and keep what works «, cult-like cultures, etc.?

Is this organization in alignment, so that people receive a consistent set of signals to reinforce behaviour that supports the core ideology and achieves desired progress?

Make your own mental list ${ }^{18}$ of specific, tangible things that make sense for you and make your organization a more visionary company, if implemented! Combine core ideology and drive for progress in terms of Table $3 .{ }^{19}$ :

\begin{tabular}{|l|l|}
\hline CORE IDEOLOGY & DRIVE FOR PROGRESS \\
\hline Provides continuity and stability. & Urges continual change for innovation. \\
Plans a relatively fixed stake in ground. & Impels constant movement (toward im- \\
Limits possibilities and directions for the & provement) \\
company. & Expands possibilities to be considered. \\
Has clear content. & Can be content free. \\
Installs a conservative act. & Can lead to dramatic, radical, revolutionary \\
& change.
\end{tabular}

\section{Table 3: Core ideology versus / and drive for progress - a systemic twinning}

\section{A Few Conclusions}

Even if you have been living in a traditional society and economy with no special tribute to innovation, you have been having and sharing a core ideology. But if may no longer fit the circumstances, if your society and economy have opened themselves to the modern market economy of the western type, which means that the buyers market has replaced the producers market and you no longer can live well without a more innovative core ideology. The biggest and oldest free-market economies also differ from each other, including the bases of their management styles (Zenko 1999). Hence, once again: it is autencity of the core ideology that matters most of all, and alignment with it inside your organization.

When working on your core ideology, try to be requisitely holistic, even if you use no words (and mathematical formulations) from the systems theory, be it the General Systems Theory or any of the younger ones, such as Critical Systems Thinking, Viable Systems Theory, Living Systems Theory, Soft Systems Methodology, Dialectical Systems Theory, etc. The same requirement, of course, applies also to making your core ideology your daily practice!

\section{Hewlett-Packard}

Technical contribution to fields in which we participate (»we exist as a corporation to make a contribution«)

Respect and opportunity for HP people, including the opportunity to share in the success of the enterprise

Contribution and responsibility to the communities in which we operate

Affordable quality for HP customers

Profit and growth as a means to make all of the other values and objectives possible

\section{IBM}

Give full consideration to the individual employee

Spend a lot of time making customers happy 
The Visionary Companies

Go the last mile to do things right; seek superiority in all we undertake

\section{Motorola}

The company exists »to honorably serve the community by providing products and services of superior quality at a fair price «

Continuous self-renewal

Tapping the »latent creative power within us«

Continual improvement in all that the company does - in ideas, in quality, in customer satisfaction

Treat each employee with dignity, as an individual

Honesty, integrity, and ethics in all aspects of business

\section{Sony}

To experience the sheer joy that comes from the advancement, application, and innovation of technology that benefits the general public

To elevate the Japanese culture and national status

Being a pioneer - not following others, but doing the impossible

Respecting and encouraging each individual's ability and creativity

\section{Enclosure $^{20}$ : Table 3.1: CORE IDEOLOGIES IN THE VISIONARY COMPANIES (Selected companies)}

This table presents the most historically consistent ideology for each of the visionary companies in our study. We did not merely paraphrase the company's most recent values, mission, vision, or purpose statement (if it had one) and we never relied on only one source; we looked for historical consistency through multiple generations of chief executives. (Comment by Collins and Porras)

\section{References}

Belak, J. (2000): Podjetnisko planiranje kot funkcija managementa. 4. spremenjena izdaja (Business Planning as a Function of Management. The 4th revised edition. In Slovenian). MER Gubno

Brudenius, C., et al. (1999): Reconstruction or Destruction? Science and Technology at Stake in Transition Economies. Universities Press, Hyderabad, India

Collins J., Porras J. (1997): Built to Last. Successful Habits of Visionary Companies. HarperBusiness, New York

Davidson, M. (1983): Uncommon Sense. The Life and Thought of Ludwig von Bertalanffy (1901-1972), Father of General Systems Theory. J. P. Tarcher, Inc., Los Angeles

Dyck, R., Mulej, M, and others (1998 and 1999): Self-Transformation of the Forgotten Four-Fifths. Kendall/Hunt, Dubuque, Iowa

Elohim, J. L. (1999): Letter to $10^{\text {th }}$ WOSC Conference, Uxbridge. (Poster)

Elohim (2000): Business Based on Bertalanffy's Weltanschauung. A Renewed Entrepreneurship Spirit is Urgently Needed. In: Rebernik, M., Mulej, M., eds.: 5 STIQE '00, Proceedings. International Conference on Linking Systems Thinking, Innovation, Quality, Entrepreneurship, and Environment. Institute for Entrepreneurship at Faculty of Economics and Business, University of Maribor

EU (1995): Green Paper on Innovation. Www.cordis.lu/cordis/grnpaper.htm

EU (2000): Communication ..: Innovation in a Knowledge-Driven Economy. Commission of the European Communities, Brussels

EMCSR (since 1972, biannually), Conference, chaired by R. Trappl, Vienna

Forrester, V. (1996): L'horreur economique. German translation: Der Terror der Oekonomie. Zsolnay, Wien (1997)

Hersh, M. (1995): The Green PC - Myth or Reality? In: M. Vezjak, E. A. Stuhler, M. Mulej, eds. (1997), referenced here 
Jackson, M. C. (1991): Systems Methodology for the Management Sciences. Plenum Press, New York, etc.

Jenner, G. (1998): Die Arbeitslose Gesellschaft. Gefaehrdet Globalisierung den Wohlstand? Fischer Tachenbuch Verlag, Franfkuft/Main

Kirn, A., ed. (1991): Ekologija, ekonomija, entropija. Aram d.o.o, Maribor

Martin, H. P., Schurmann, H. (1996): Globalisierungsfalle. Rowohlt Verlag, Muenchen

Milosevic, N. (2000): Think Different. New Moment, 14

Mulej, M. (2000): Basics of Systems Thinking (Applied to Innovation Management).University of Maribor, Faculty of Economics and Business, International Program FEBA

Mulej, M., in soavtorji (= et al.) (2000): Dialekticna in druge mehkosistemske teorije (podlaga za celovitost in uspeh managementa). (The Dialectical and other Soft-Systems Theories - a Basis for Wholism and Success of Management. In Slovenian). University of Maribor, Faculty of Economics and Business

Mulej, M., Kajzer, S. (1998): Ethics of Interdependence and the Law of Requisite Holims. In: Rebernik, M., Mulej, M., eds. (1998): The 4th STIQE '98. Proceedings. Institute for Systems Research, Maribor, et al.

Mulej, M., Kajzer, S., Potocan, V., Knez-Riedl, J. (2000) Which systems theories support realization of the Local Agenda 21 ? (Invited introductory plenary talk to the $17^{\text {th }}$ International and Transdisciplinary Conference, sponsored by WACRA Europe e.V. "Change and Flowing Equilibria, Local Agenda 21 and Business Interests", in Vipiteno / Sterzing, Italy, on 25-27 Sept., 2000; edited by: T. Ecimovic and E. Stuhler)

Pecjak, V. (2001): Poti do novih idej. / Ways to New Ideas. / Putevi do novih ideja. (Slovenian, English and Serbian edition). New Moment, 16

Potocan, V. (2001): Information Support to and by Business and Soft Systems Theories in the Perspectives of the Law of Requisite Holism In: Chroust, G., Hofer, C., eds.: Proceedings of the 9th IDIMT (Interdisciplinary Information Management Talks). Universitaetsverlag Rudolf Trauner, Linz

Rebernik, M., Mulej, M. (2000): Requisite holism, isolating mechanisms and entrepreneurship. Kybernetes, 29, 9/10, pp. 13061323

Rogers, E. (1995): Diffusion of Innovations, Fourth Edition. The Free Press, New York etc.

Vezjak, M., Stuhler, E., Mulej, M., eds. (1997): Environmental Problem Solving - From Cases and Experiments to Concepts, Knowledge, Tools, and Motivation. Rainer Hampp Verlag, Muenchen

Zenko, Z. (1999): Comparative Analysis of Management Models of Japan, USA, and Europe. Dr. Diss., University of Maribor

Zenko, Z. (1999): Participative Management in Japan, USA, and Europe. Systemica

\footnotetext{
${ }^{1}$ The contribution is based on research program "Innovative Enterprise in Transition", which is sponsored by the Ministry of Education, Science and Sports, Republic of Slovenia, in 1999-2003.

${ }^{2}$ Invention is defined as a result of creativity promising a potential benefit, but not able to yield it yet. It may come to be forgotten about or to be invested in thus to develop to a potential innovation, first, and to an innovation, later on. It may also find a market of its own, the customers would be the entrepreneurs who are willing to take a lot of risk of investment into R\&D, production and marketing etc.

${ }^{3}$ A potential innovation is further developed than an invention. It is already usable, but has not yet found its place in the usual market, the customers being either internal or external or both. Thus, it is not yet an innovation. Its market may make entrepreneurs who are not willing to take the risk of $R \& D$, but the one of investment into production and marketing etc.

${ }^{4} \mathrm{An}$ innovation is any novelty, which has already found a positive response with its potential customers. It may be technological or non-technological in its contents. (See: EU 1995; EU 2000)

${ }^{5}$ Examples from research conducted over six years and based on studying close to 100.000 pages of documents of and on companies which are found the best ones in the world over several decades. On average the selected companies have about one hundred years of age. See: Collins, J. C., and J. I. Porras (1997) In 1994-1997 there were more than forty printings of this book worldwide, translations in thirteen languages, best-seller status in North America, Japan, South America, parts of Europe. Newer editions are also available.
} 
${ }^{6}$ See e.g. journals such as Systems Research and Behavioral Science; Cybernetics and Systems, an International Journal; Kybernetes; Systemica; books in the book series edited by G. J. Klir; Mulej, 2000; etc.

${ }^{7}$ About the Mulej/Kajzer law of requisite holism see: Mulej, Kajzer 1998; Rebernik, Mulej 2000; Mulej et al. 2000.

${ }^{8}$ As long as only partial problems are tackled, this may be good enough. But it may lead to suboptimization, which may work against a holistic optimization. An informatics case: seeing technology in network with finance, marketing, production and human resources, or without their interdependencies, etc.

${ }^{9}$ In both the personal contacts and texts by a number of authors we read from around the world, we very rarely come across the notions of interdependence and interdisciplinarity. Several authors tend to talk about transdisciplinarity in a way meaning that the general attributes from different disciplines are searched for isomorphysms, rather then cooperation of mutually different disciplines and hence viewpoints.

${ }^{10}$ Every specialization in both practice and science is (unavoidably and also usefully, to some extent) limited to reducing the total amount of the really existing attributes to the ones, which are exposed by its selected viewpoint. The formal notion of the system (an ordered set, made of a set of elements and a set of relations) is still met, even from a single viewpoint. Hence, in terms of contents, a fictitious holism may result. Consequences may be quite bad surprises.

${ }^{11}$ We do not dare speaking for altruism. We speak of interdependence as the precondition for the selfish interest to be met. E.g.: your personal experience may say that you tend to not return to a supplier with whom you do not feel satisfied.

${ }^{12}$ These days and years, one hears a lot of globalization, with full right. Interests of the ones, who can make impact over the entire Globe, are crucial determinants of our lives. But we keep living locally, mostly, at least. This may be reasons for social scientist to coin the word "glocalisation" recently. Global and local attributes are selected from the same life on the basis of different selected viewpoints, each one of them expressing a (different!) part of the real system of attributes. For a holistic picture, they need to be found interdependent rather than independent, obviously.

${ }^{13}$ We have not yet heard of any conference of United Nations, which would require businesses to keep to systems thinking on the level of interests of the entire mankind, when doing business. This requirement might be comparable with the requirement for the care for sustainable development. But we can report of other similar new globally valid decisions: ISO 9000 which deals with quality of business, requires systems thinking in its new edition called ISO 2000; EQA - European Quality Award similarly quotes learning and innovation as its basis (and there is no transition from invention to innovation with a lack of systems thinking). (see: Mulej et al, 2000). A new document by European Union concerning innovation explicitly requires systems thinking (EU 2000).

${ }^{14}$ With the economically most advanced areas of the world, the North America, Western Europe, and Japan plus a few smaller nations such as Singapore, South Korea, Hong-Kong, Taiwan, Australia, New Zealand, which make 20\% of mankind, the invisible hand of the market pressure has produced quite a lot of both theory and practice of systems thinking, on their own terms. In the areas with other cultures, such as South America, Africa, most of Asia, the less advanced / industrialized and postindustrialized part of Europe, the market pressure has not (yet) been able to develop its impact in the same direction. They may be backward or simply different in their culture(s). (Zenko, 1999; Dyck, Mulej, 1998; etc.)

${ }^{15}$ See enclosure about their formulations in some of the discussed visionary companies.

${ }^{16}$ This statement is very close to systems thinking, but it still does not use the words of its language.

${ }^{17}$ See enclosure.

${ }^{18}$ Please, do not consider this brief article a sufficient basis. This is a summary and a very brief one.

${ }^{19}$ Our personal core ideology may read, since we are professors of systems and innovation theory, and management and organization, resp., as follows and be used as the basic criterion for any decision: Help people consider everything essential and cooperate creatively with others, mostly of other professions, to produce inventions and transform them to innovations $(=$ new benefit) by a requisitely holistic management.

${ }^{20}$ This table is from Collins/Porras (1997), too. We selected a quote concerning the information companies, because we lack room. 